\title{
PENERAPAN ULANGAN BERBASIS ANDROID UNTUK MENINGKATKAN KOMPETENSI GURU DI SMAN 1 BELIMBING KABUPATEN MELAWI
}

\author{
Nia Daniati \\ SMAN 1 Belimbing \\ Email:nia1980sma2@gmail.com
}

\begin{abstract}
This study aims to improve the competence of Teachers of SMAN 1 Belimbing Melawi Regency. This research is a School Action Research. The subjects of this research were 28 teachers from SMA Negeri 1 Belimbing, consisting of 17 women and 11 men. Data collection techniques are done using questionnaires, interviews, observation sheets of teacher activities, notes and documentation. Analysis of the data used is descriptive qualitative. The results of this study indicate that the application of an Android-based test using Google form in the midterm and Midterm Assessments can improve teacher competency. This is seen based on the evidence of an increase in teachers who achieve understanding and can make questions based on android from pre-action, Cycle I and Cycle II. In cycle 1, as many as 21 teachers or $75 \%$ already understood the steps of making test questions based on android then in the second cycle, as many as 27 teachers or $96.43 \%$ of teachers were able to apply android-based tests in the final semester evaluation effectively and efficiently
\end{abstract}

\section{Keywords: Android-based test, Teacher Competency, Google Form}

\section{PENDAHULUAN}

Pada era digital ini, peran guru sangatlah penting, selain mendidik dan mengajar, guru diwajibkan menjadi kreatif. Guru kreatif adalah guru yang mampu mengajar dengan mamadukan penguasaan pengetahuan, kemampuan publik speaking, memiliki ragam ice breaking, menampilkan slide yang komunikatif, memiliki video menarik, membuat semua siswa-siswi bisa berpendapat dan memanfaatkan teknologi dan internet sebagai media pembelajaran. Guru harus selalu melakukan inovasi dan meningkatkan kompetensi diri untuk menciptakan sumber daya manusia yang handal dan profesional sebagai indikator bahwa pembelajaran berjalan efektif dan efisien. Sumber daya manusia yang memiliki daya saing global harus dipersiapkan mulai sekarang, salah satu caranya adalah mengoptimalkan pembelajaran dengan teknologi. Di samping dibekali dengan ilmu pendidikan, peserta didik hendaknya diimbangi dengan kemampuan mengoperasikan dan memanfaatkan teknologi.
Inovasi yang dapat dilakukan guru yaitu melalui teknologi pembelajaran. Teknologi pembelajaran dapat diartikan sebagai teori dan praktik dalam pembelajaran, yang dimulai dari desain, pengembangan, pemanfaatan, pengelolaan serta evaluasi pembelajaran (Mardiana \& Purwanto, 2017). Guru harus dapat menyesuaikan dan beradaptasi dengan lingkungan global yang terus menerus mengalami perkembangan dengan pesat. Kompetensi abad 21 menuntut agar peserta didik terlibat langsung dalam proses pembelajaran yang memanfaatkan fasilitas internet, dimana peserta didik bukan hanya sebatas mencari informasi, tapi peserta didik juga melaksanakan pembelajaran serta evaluasi secara online (Sohibun \& Ade, 2018). Banyak strategi maupun metode yang dapat digunakan guru dalam pemanfaatan teknologi untuk meningkatkan kualitas dalam melakukan evaluasi pembelajaran.

Guru SMAN 1 Belimbing mempunyai potensi yang baik dalam mengembangkan teknologi dan penggunaan internet didukung oleh adanya fasilitas yang memadai seperti 
komputer, jaringan internet, handphone android namun hampir semua guru masih menggunakan cara konvensional yaitu mennggunakan sistem evaluasi berbasis kertas. Untuk meningkatkan kompetensi maka perlu adanya diklat tentang pembuatan soal ulangan berbasis android dan menerapkan soal yang telah dibuat pada Penilaian Tengah semester dan Penilaian akhir semester.

Dengan model evaluasi daring (online) ini diharapkan dapat meningkatkan efektivitas, efisiensi, minat, dan inovasi yang dilakukan oleh guru serta meningkatkan kualitas pembelajaran secara umum. Salah satu aplikasi yang dapat digunakan secara gratis dari google untuk membantu guru dalam penyusunan evaluasi online adalah google form.

Berdasarkan latar belakang masalah di atas, maka penulis dapat mengidentifikasi masalah yaitu: (1) Kompetensi Guru dalam menerapkan Ulangan berbasis android masih rendah; (2) Rendahnya pelatihan yang diadakan dalam rangka meningkatkan kompetensi guru; (3) Sistem Ulangan berbasis android masih belum efektif dengan terkendala masalah/teknis/Jaringan dan (4) Penerapan ulangan berbasis android dapat meningkatkan minat belajar siswa dalam mempelajari teknologi.

Sehubungan hal tersebut penulis tertarik untuk mengadakan penelitian dengan judul "Penerapan ulangan berbasis android untuk meningkatkan kompetensi guru di SMAN 1 Belimbing Kabupaten Melawi.

\section{Kompetensi Guru}

Dalam Kamus Besar Bahasa Indonesia kata kompetensi berarti "kewenangan (kekuasaan) untuk menentukan atau memutuskan sesuatu hal". Kata kompetensi secara harfiah dapat diartikan sebagai "kemampuan". Kata ini sekarang menjadi kunci dalam dunia pendidikan. Dengan memiliki kompetensi yang memadai, khususnya seorang guru dapat melaksanakan tugasnya dengan baik. Bisa dibayangkan bagaimana jadinya dunia pendidikan jika para gurunya tidak memiliki kompetensi memadai. Makna penting kompetensi dalam dunia pendidikan didasarkan atas pertimbangan rasional bahwasanya proses pembelajaran merupakan proses yang rumit dan kompleks

Kompetensi guru adalah seperangkat penguasaan, kemampuan yang harus ada dalam diri guru agar dapat mewujudkan kinerjanya secara tepat dan efektif. Sedangkan Kompetensi merupakan perilaku rasional guna mencapai tujuan yang dipersyaratkan sesuai dengan kondisi yang diharapkan, dengan demikian suatu kompetensi ditunjukkan oleh penampilan atau kerja yang dapat dipertanggung jawabkan (rasional) dalam upaya mencapai tujuan.

Dengan mempunyai kompetensi, guru akan semakin sadar bahwa kemampuan dan keterampilan akan menjadi penting ketika sudah dihadapkan dengan perkembangan zaman dalam perkembangan teknologi yang sangat pesat.

Dalam undang-undang Guru dan Dosen NO. 14/2005 dan Peraturan Pemerintah No. 19/2005 dinyatakan bahwa "kompetensi guru meliputi kompetensi kepribadian, pedagogik professional, dan sosial".

Kompetensi kepribadian merupakan "kemampuan yang mencerminkan kepribadian mantap, stabil, dewasa, arif, dan berwibawa, menjadi teladan bagi peserta didik dan berakhlak mulia". Secara rinci Farida Sarimaya (20-21) subkompetensi dapat dijabarkan sebagai berikut: (1) Subkompetensi kepribadian yang mantab dan stabil memiliki indikator esensial: bertindak sesuai dengan norma hukum, bertindak sesuai dengan norma sosial, bangga sebagai guru, dan memiliki konsistensi dalam bertindak sesuai dengan norma; (2) Subkompetensi kepribadian yang dewasa memiliki indikator esensial: menampilkan kemandirian dalam bertindak sebagai pendidik dan memiliki etos kerja sebagai guru; (3) Subkompetensi kepribadian yang arif memiliki indikator esensial: menampilkan tindakan yang didasarkan pada kemanfaatan peserta didik, sekolah, dan masyarakat serta menunjukkan keterbukaan dalam berfikir dan bertindak; (3) Subkompetensi kepribadian yang berwibawa memiliki indikator esensial: memiliki perilaku yang berpengaruh positif terhadap peserta 
didik dan memiliki perilaku yang disegani; (4) Subkompetensi akhlak mulia dan dapat menjadi teladan memiliki indikator esensial: bertindak sesuai norma religius (iman dan takwa, jujur, ikhlas, suka menolong), dan memiliki perilaku yang diteladani peserta didik; dan (5) Subkompetensi evaluasi diri dan pengembangan diri memiliki indikator esensial: memilki kemampuan untuk berintropeksi, dan mampu mengembangkan potensi diri secara optimal.

Kompetensi pedagogik dijelaskan dalam Standar Nasional Pendidikan pasal 26 ayat 3 butir a dikemukakan bahwa kompetensi pedagogik adalah Kemampuan mengelola pembelajaran peserta didik yang meliputi pemahaman terhadap peserta didik, perencanaan dan pelaksanaan pembelajaran, evaluasi hasil belajar, dan pengembangan peserta didik untuk mengaktualisasikan berbagai potensi yang dimilikinya.

Kompetensi profesional adalah "kompetensi atau kemampuan yang berhubungan dengan penyelesaian tugastugas keguruan". Kompetensi ini merupakan kompetensi yang sangat penting, oleh sebab langsung berhubungan dengan kinerja yang ditampilkan. Oleh sebab itu tingkat keprofesionalan seorang guru dapat dilihat dari kompetensi ini. Kompetensi profesional adalah kemampuan dalam penguasaan akademik (mata pelajaran/bidang studi) yang diajarkan dan terpadu dengan kemampuan mengajarnya sekaligus sehingga guru memiliki wibawa akademik. Dalam Standar Nasional Pendidikan, penjelasan pasal 28 ayat 3 butir c dikemukakan bahwa yang dimaksud dengan kompetensi profesional adalah Kemampuan penguasaan materi pembelajaran secara luas dan mendalam yang memungkinkan membimbing peserta didik memenuhi standar kompetensi yang ditetapkan dalam Standar Nasional Pendidikan. Kompetensi profesional merupakan penguasaan materi pembelajaran secara luas dan mendalam, yang mencangkup penguasaan materi kurikulum mata pelajaran di sekolah dan subtansi keilmuan yang menaungi materinya, serta penguasaan terhadap struktur dan metodologi keilmuannya.

Kompetensi sosial merupakan kemampuan guru untuk berkomunikasi dan bergaul secara efektif dengan peserta didik, sesama pendidik, tenaga kepandidikan, orang tua/wali peserta didik, dan masyarakat sekitar. Kompetensi sosial yaitu perangkat perilaku tertentu yang merupakan dasar dari pemahaman diri sebagai bagian yang tidak terpisahkan dari lingkungan sosial serta tercapainya interaksi sosial secara efektif.Kompetensi ini memiliki subkompetensi dengan indikator esensial sebagai berikut: (1) Mampu berkomunikasi dan bergaul secara efektif dengan peserta didik., subkompetensi ini memiliki indikator esensial: berkomunikasi secara efektif dengan peserta didik. (2) Mampu berkomunikasi dan bergaul secara efektif dengan sesama pendidik dan tenaga pendidik; dan (3) Mampu berkomunikasi dan bergaul secara efektif dengan orang tua/wali peserta didik dan masyarakat sekitar.

Perlu dijelaskan bahwa sebenarnya keempat kompetensi (kepribadian, pedagogik, professional, dan sosial) tersebut dalam praktiknya merupakan satu kesatuan yang utuh (holistik) yang dapat diperoleh melalui pendidikan akademik sarjana atau diploma empat, pendidikan profesi ataupun melalui pembinaan dan pengembangan profesi guru. Pembinaan dan pengembangan profesi guru dalam jabatan dapat dimanfaatkan baik untuk pengembangan potensi maupun untuk pengembangan karir guru.

\section{Pengertian Android}

Android adalah sistem operasi yang berbasis linux untuk telepon seluler yang dikembangkan oleh dua jenis distributor sistem operasi yaitu Google atau Google Mail Services (GMS) dan Open Handset Distribution (OHD). Sampai saat ini, android memiliki tujuh macam versi yang semua versinya diberi nama berdasarkan nama makanan antara lain Cupcake, Donut, Eclair, Frozen Yogurt, Gingerbread, Honeycomb, Ice Cream Sandwich, Jelly Bean dan versi terbarunya yaitu KitKat. 
Hasil survey yang dilakukan Opera pada tahun 2013 di Indonesia menunjukkan bahwa $10 \%$ pengguna android adalah umur 13-17 tahun, hal ini membuktikan bahwa anak dengan usia tingkat SMP sampai SMA memili perhatian yang cukup besar dalam penggunaan smartphone.

Dunia pendidikan tidak terlepas dari proses pembelajaran yang meliputi, guru, siswa dan lingkungan pembelajaran yang saling mempengaruhi satu sama lain. Media merupakan salah satu faktor penunjang tercapainya tujuan pembelajaran. Hal ini berkaitan dengan penggunaan media yang tepat dan bervariasi dalam proses pembelajaran dapat meningkatkan motivasi belajar dan dapat mengurangi sikap pasif siswa.

\section{Pengertian Google Form}

Google form adalah salah satu produk dari google dari kategori produk google docs. Google form merupakan webbase application yang memberikan layanan untuk membuat form untuk berbagai kepentingan seperti, membuat soal ulangan/tes, survey, buku tamu, pengumpulan data, dan lain sebagainya.

Google form adalah aplikasi gratis yang disediakan oleh google yang dapat digunakan untuk menyusun tes online secara cepat dan mudah. Google form sangat tepat digunakan oleh guru untuk membuat kuis/ulangan harian, form dan survey secara online (Batubara, 2016). Beberapa fasilitas yang disediakan oleh google form, yaitu mendesain formulir online untuk kuis/ulangan harian dengan bentuk pertanyaan yang berbeda, memodifikasi google form dengan menggunakan template, membagikan google form yang telah dibuat, menempelkan form tes/ujian online yang telah dibuat dalam blog atau website (Mutadi, 2018). Sebelum membuat dan menggunakan salah satu fitur google docs seperti google form maka kita disyaratkan untuk memiliki akun universal Google yang terintegrasi untuk menikmati seluruh fitur layanan gratis google. Caranya dengan mendaftar di http://account.google.com/login. Dengan memiliki akun tersebut, maka akan bisa menggunakan berbagai produk google yang dirilis secara gratis, seperti gmail sebagai alat untuk berkomunikasi email, google drive sebagai alat penyimpanan file secara online dengan kapasitas $15 \mathrm{~GB}$, youtube sebagai alat berbagi dan menyimpan video, google site sebagai alat untuk membuat website sederhana, blogger sebagai alat untuk membuat blog, google classroom sebagai alat untuk membuat kelas virtual, google play sebagai alat untuk berbagi aplikasi dan lain sebagainya (Batubara, Hamdan Husein, 2016)

\section{METODE PENELITIAN}

Penelitian ini dilaksanakan di SMAN 1 Belimbing. Subjek dalam penelitian ini adalah Guru di SMAN 1 Belimbing yang berjumlah 28 Guru, yang terdiri atas 17 perempuan dan 11 laki-laki. Pendekatan yang digunakan dalam penelitian ini adalah pendekatan kualitatif dan kuantitatif. Data penelitian kualitatif diambil secara alami berupa katakata atau gambar. Data yang diperoleh dari hasil penelitian kualitatif misalnya saja hasil pengamatan, observasi, dokumentasi.

Penelitian ini diawali dengan observasi dan wawancara yang dilaksanakan pada bulan Juli 2019. Pada bulan Agustus 2019 penelitian dilanjutkan dengan pembuatan instrument. Pelaksanaan penelitian dengan melaksanakan pelatihan dan menerapkan Ulangan Berbasis android dilaksanakan pada bulan September dan November tahun 2019. Model penelitian pada penelitian ini merujuk pada proses pelaksanaan penelitian yang dikemukakan oleh Kemmis dan Taggart (Suwarsih Madya, 1994: 25) meliputi menyusun rencana tindakan, bertindak, melakukan refleksi dan merancang tindakan selanjutnya. Rencana pratindakan meliputi (1) menentukan masalah; (2) menentukan analisis prioritas masalah; (3) menentukan fakta Keberadaan masalah; (4) menentukan penyebab masalah; (5) menentukan alternative tindakan; (6) menentukan tindakan yang di pilih; (7) Menentukan alasan tindakan yang dipilih; dan (8) merumuskan masalah

Pelaksanaan tindakan di Siklus 1 (1) Pada awal pembelajaran peneliti mengundang nara sumber untuk melakukan pelatihan kepada 
guru dalam kegiatan pelatihan penerapan ulangan berbasis android; (2) Materi yang diberikan terkait dengan penggunaan Android dalam pelaksanaan ulangan; (3) Guru mendengarkan materi yang disampaikan; dan (4) Guru menerapkan Ulangan berbasis android pada Penilaian Tengah Semester. Pengamatan dilakukan oleh pengamat (peneliti) selama proses pelatihan berlangsung terhadap aktivitas guru. Pengamatan dilakukan berdasarkan panduan observasi yang dilakukan dengan mengisi lembar observasi yang telah dipersiapkan. Hasil evaluasi yang telah diperoleh dapat dijadikan dasar untuk melakukan refleksi. Refleksi dilakukan dengan pengungkapan hasil pembelajaran pada waktu pelatihan dan tindakan-tindakan yang dilakukan oleh guru. Berdasarkan hasil refleksi ini dapat dijadikan perbaikan pada siklus selanjutnya.Tahapan tersebut dilaksanakan pada siklus I, dan dilanjutkan pada siklus berikutnya hingga mengalami peningkatan. Penyusunan desain dilakukan terus menerus sampai disimpulkan hasil yang setara sesuai dengan harapan dan terdiri dari beberapa siklus, bila siklus pertama belum berhasil, maka akan dilanjutkan dengan siklus berikutnya.Hasil analisis data dan refleksi digunakan untuk memutuskan apakah tindakan yang dilakukan pada siklus 1 dapat mengatasi masalah dengan baik. Jika belum optimal maka akan dilanjutkan dengan siklus berikutnya dengan desain penelitian yang sama dan penerapan Ulangan Berbasis android pada Penilaian Akhir Semester. Adapun tehnik pengumpulan data dengan observasi dan dokumentasi. Penelitian tindakan kelas dimaksudkan untuk meningkatkan prestasi membaca siswa, maka dari itu keberhasilan penelitian tidakan ini ditandai dengan adanya peningkatan prestasi membaca siswa ke arah yang lebih baik. Suharsimi Arikunto (2008:90). Indikator keberhasilan penelitian secara kualitatif adalah: (1)Adanya peningkatan aspek kerjasama dan partisipasi guru dalam mempelajari langkah-langkah menyusun soal ulangan berbasis android; (2) Adanya peningkatan aktivitas guru dengan menerapkan Soal Ulangan Berbasis android pada Penilaian Tengah Semester dan Penilaian Akhir Semester. Secara Kuantitatif ditandai dengan (1) Kompetensi Guru berdasarkan hasil evaluasi meningkat dari siklus I ke siklus II; (2) Persentase Aktivitas guru meningkat dari siklus I ke siklus II; dan (3) Ketuntasan kompetensi guru dengan menerapkan ulangan berbasis android dalam satu sekolah telah mencapai $90 \%$ dari jumlah total guru dalam satu sekolah.

\section{HASIL DAN PEMBAHASAN PENELITIAN}

Gambaran umum sebelum melakukan tindakan dapat terlihat dari hasil Angket pratindakan adalah sebagai berikut:

Tabel 1. Hasil Angket Pratindakan

\begin{tabular}{clcccc}
\hline No & \multicolumn{1}{c}{ Indikator } & \multicolumn{3}{c}{ Pernyataan } \\
\cline { 3 - 5 } & \multicolumn{2}{c}{ Ya } & \multicolumn{2}{c}{ Tidak } \\
\hline $\mathbf{1}$ & $\begin{array}{l}\text { Apakah anda paham fungsi Google } \\
\text { drive? }\end{array}$ & 14 Guru & $50 \%$ & 14 Guru & $50 \%$ \\
\hline $\mathbf{2}$ & $\begin{array}{l}\text { Apakah anda faham tentang pelaksanaan } \\
\text { Ulangan berbasis Android? }\end{array}$ & 2 Guru & $7,14 \%$ & 26 Guru & $92,86 \%$ \\
\hline $\mathbf{3}$ & $\begin{array}{l}\text { Apakah anda pernah menerapkan } \\
\text { ulangan berbasis Android? }\end{array}$ & 2 Guru & $7,14 \%$ & 26 Guru & $92,86 \%$ \\
\hline $\mathbf{4}$ & $\begin{array}{l}\text { Apakah anda memahami cara } \\
\text { bagaimana memberikan link ujian } \\
\text { kepada siswa? }\end{array}$ & 2 Guru & $7,14 \%$ & 26 Guru & $92,86 \%$ \\
\hline
\end{tabular}




\section{Apakah anda pernah memeriksa lembar $\quad 2$ Guru $\quad 7,14 \% \quad 26$ Guru $\quad 92,86 \%$ jawaban siswa dengan menggunakan teknologi?}

Berdasarkan hasil angket yang dibagikan kepada guru dari perolehan prosentase pada setiap indikator pernyataan dapat dinyatakan bahwa kompetensi guru yang dimiliki guru SMAN 1 Belimbing tentang Ulangan berbasis android sangat rendah, untuk itu perlu diadakan pelatihan penggunaan android untuk Ulangan. Setelah dilakukan survey dengan koresponden sebanyak 28 guru, sekitar 89,29 $\%$ menyatakan sangat setuju diadakan pelatihan penerapan ulangan berbasis android untuk meningkatkan kompetensi guru.Pentingnya pelatihan Pembuatan
Ulangan Berbasis Android dilaksanakan untuk meningkatkan kompetensi guru

\section{Siklus 1}

Pada siklus 1 ini, penelitian dilaksanakan 1 kali pertemuan yaitu Pelatihan Pembuatan Ulangan berbasis Android bertujuan untuk menjelaskan tentang langkah-langkah membuat ulangan berbasis Android dan peniliti melihat Sikap guru pada saat pelatihan.

Tabel 2. Hasil Pengamatan Sikap Guru di Siklus I

\begin{tabular}{|c|c|c|c|c|c|}
\hline \multirow{3}{*}{$\begin{array}{l}\text { No } \\
1\end{array}$} & \multirow{3}{*}{$\begin{array}{l}\text { Indikator Aktivitas } \\
\text { Datang tepat waktu }\end{array}$} & \multicolumn{4}{|c|}{ Pernyataan } \\
\hline & & \multicolumn{2}{|c|}{ Ya } & \multicolumn{2}{|c|}{ Tidak } \\
\hline & & 27 Guru & $96,43 \%$ & 1 Guru & $3,57 \%$ \\
\hline 2 & $\begin{array}{l}\text { Tekun dalam mengikuti } \\
\text { pelatihan }\end{array}$ & 4 Guru & $14,29 \%$ & 24 Guru & $85,71 \%$ \\
\hline 3 & Aktif bertanya & 6 Guru & $21,43 \%$ & 22 Guru & $78,57 \%$ \\
\hline 4 & $\begin{array}{l}\text { Tanggung jawab dengan } \\
\text { tugas yang diberikan }\end{array}$ & 22 Guru & $78,57 \%$ & 6 Guru & $21,43 \%$ \\
\hline 5 & $\begin{array}{l}\text { Dapat mengikuti } \\
\text { langkah-langkah yang } \\
\text { diinstruksi pelatih dan } \\
\text { menyelesaikan pekerjaan } \\
\text { tepat waktu }\end{array}$ & 21 Guru & $75 \%$ & 7 Guru & $25 \%$ \\
\hline
\end{tabular}

Berdasarkan hasil pengamatan peneliti, aktivitas guru dalam kegiatan pelatihan pembuatan ulangan berbasis android pada siklus 1, Guru mempunyai motivasi yang tinggi untuk mengikuti pelatihan dilihat dari kehadiran semua guru datang tepat waktu, tekun dalam mengkuti pelatihan, aktif bertanya, tanggung jawab dengan tugas yang diberikan dan dapat mengikuti langkahlangkah instruksi pelatih dan menyelesaikan pekerjaan tepat waktu

Tabel 3. Deskripsi Pengamatan Tindakan Yang Dilakukan Selama Siklus I Terhadap Aktivitas Guru

\begin{tabular}{llll} 
No Indikator Aktivitas & Ya & Pernyataan & \\
\cline { 3 - 4 } & & Tidak
\end{tabular}




\begin{tabular}{|c|c|c|c|c|c|}
\hline 1 & $\begin{array}{l}\text { Guru melakukan } \\
\text { konfigurasi akun } \\
\text { google/google drive }\end{array}$ & 14 Guru & $50 \%$ & 14 Guru & $50 \%$ \\
\hline 2 & $\begin{array}{l}\text { Guru melakukan login akun } \\
\text { google }\end{array}$ & 22 Guru & $78,57 \%$ & 6 Guru & $21,43 \%$ \\
\hline 3 & $\begin{array}{l}\text { Guru melakukan } \\
\text { pembuatan template soal }\end{array}$ & 16 Guru & $57,14 \%$ & 12 Guru & $42,86 \%$ \\
\hline 4 & Guru melakukan input soal & 24 Guru & $85,71 \%$ & 4 Guru & $14,29 \%$ \\
\hline 5 & $\begin{array}{l}\text { Guru melakukan } \\
\text { penyetingan form limiter }\end{array}$ & 21 Guru & $75 \%$ & 7 Guru & $25 \%$ \\
\hline 6 & $\begin{array}{l}\text { Guru mengecek kesiapan } \\
\text { android siswa berkaitan } \\
\text { dengan jaringan internet }\end{array}$ & 28 Guru & $100 \%$ & 0 Guru & $0 \%$ \\
\hline 7 & $\begin{array}{l}\text { Guru melakukan } \\
\text { pengiriman link ujian }\end{array}$ & 11 Guru & $39,29 \%$ & 17 Guru & $60,71 \%$ \\
\hline 8 & $\begin{array}{l}\text { Guru membuat group WA } \\
\text { kelas }\end{array}$ & 28 Guru & $100 \%$ & 0 Guru & $0 \%$ \\
\hline 9 & $\begin{array}{l}\text { Guru melakukan } \\
\text { pengiriman link ujian ke } \\
\text { grup WA siswa }\end{array}$ & 28 Guru & $100 \%$ & 0 Guru & $0 \%$ \\
\hline 10 & $\begin{array}{l}\text { Guru dapat melihat hasil } \\
\text { ujian }\end{array}$ & 18 Guru & $64,29 \%$ & 10 Guru & $35,71 \%$ \\
\hline
\end{tabular}

Pada siklus 1, guru dapat mengoperasikan dan menerapkan Ulangan berbasis android pada Penilaian Tengah semester mencapai $75 \%$. Meskipun mengalami beberapa kendala seperti sinyal internet yang kurang stabil, penyetingan durasi waktu ulangan pada form limiter banyak terlewatkan sehingga ketika ulangan berlangsung belum ada batas waktu pengerjaan soal dan siswa masih menyelesaikan soal pada beberapa waktu berikutnya, ada beberapa guru yang lupa membuat grup WA, ketika link ujian akan dibagikan sehingga proses ulangan berjalan lambat. Melihat dari hasil observasi pada siklus 1 maka peneliti merasa perlu untuk mengadakan pertemuan berikutnya pada siklus II.

\section{Siklus II}

Kegiatan pembelajaran pada siklus II ini merupakan perbaikan dari siklus I dan berusaha membenahi kekurangan pada siklus I tersebut. Kegiatan yang akan dilakukan pada tahap perencanaan ini adalah : (1) Guru menyiapkan soal ulangan yang telah disusun untuk Penilaian Akhir semester; (2) Guru menyiapkan perbaikan-perbaikan sebagai refleksi dari siklus I dan (3) Peniliti mengamati sikap guru pada saat pelatihan.

Tabel 4. Hasil Pengamatan Sikap Guru di Siklus II

\begin{tabular}{|c|c|c|c|}
\hline \multirow[t]{2}{*}{ No } & \multirow[t]{2}{*}{ Indikator Aktivitas } & \multirow{3}{*}{$\begin{array}{c}\text { Pernyataan } \\
\text { Ya } \\
\end{array}$} & Pernyataan \\
\hline & & & $\begin{array}{l}\text { Tidak } \\
\end{array}$ \\
\hline 1 & Datang tepat waktu & & 0 Guru \\
\hline
\end{tabular}




\begin{tabular}{clcccc}
\hline $\mathbf{2}$ & Tekun dalam mengikuti & 27 Guru & $96,43 \%$ & $1 \mathrm{Guru}$ & $3,57 \%$ \\
& pelatihan & & & & \\
\hline $\mathbf{3}$ & Aktif bertanya & 21 Guru & $75 \%$ & 7 Guru & $25 \%$ \\
\hline $\mathbf{4}$ & $\begin{array}{l}\text { Tanggung jawab dengan } \\
\text { tugas yang diberikan }\end{array}$ & 26 Guru & $92,86 \%$ & 2 Guru & $7,14 \%$ \\
\hline $\mathbf{5}$ & $\begin{array}{l}\text { Dapat mengikuti langkah- } \\
\text { langkah yang diinstruksi } \\
\text { pelatih dan menyelesaikan } \\
\text { pekerjaan tepat waktu }\end{array}$ & 27 Guru & $96,43 \%$ & 1 Guru & $3,57 \%$ \\
\hline
\end{tabular}

Berdasarkan hasil pengamatan peneliti, aktivitas guru dalam kegiatan pelatihan pembuatan ulangan berbasis android pada siklus 1I, Guru mempunyai motivasi yang tinggi untuk mengikuti pelatihan dilihat dari kehadiran semua guru datang tepat waktu, tekun dalam mengkuti pelatihan, aktif bertanya, tanggung jawab dengan tugas yang diberikan dan dapat mengikuti langkahlangkah instruksi pelatih dan menyelesaikan pekerjaan tepat waktu.

Tabel 5. Deskripsi Pengamatan Tindakan Yang Dilakukan Selama Siklus II Terhadap Aktivitas Guru

\begin{tabular}{|c|c|c|c|c|c|}
\hline \multirow{3}{*}{$\begin{array}{c}\text { No } \\
1\end{array}$} & \multirow{3}{*}{\begin{tabular}{l}
\multicolumn{1}{c}{ Indikator Aktivitas } \\
Guru melakukan konfigurasi \\
akun google/google drive
\end{tabular}} & \multirow{2}{*}{\multicolumn{2}{|c|}{$\frac{\text { Pernyataan }}{\text { Ya }}$}} & \multirow{2}{*}{\multicolumn{2}{|c|}{$\begin{array}{c}\text { Pernyataan } \\
\text { Tidak }\end{array}$}} \\
\hline & & & & & \\
\hline & & 28 Guru & $100 \%$ & 0 Guru & $0 \%$ \\
\hline 2 & $\begin{array}{l}\text { Guru melakukan login akun } \\
\text { google }\end{array}$ & 28 Guru & $100 \%$ & 0 Guru & $0 \%$ \\
\hline 3 & $\begin{array}{l}\text { Guru melakukan pembuatan } \\
\text { template soal }\end{array}$ & 23 Guru & $82,14 \%$ & 5 Guru & $17,86 \%$ \\
\hline 4 & Guru melakukan input soal & 28 Guru & $100 \%$ & 0 Guru & $0 \%$ \\
\hline 5 & $\begin{array}{l}\text { Guru melakukan } \\
\text { penyetingan form limiter }\end{array}$ & 24 Guru & $85,71 \%$ & 4 Guru & $14,29 \%$ \\
\hline 6 & $\begin{array}{l}\text { Guru mengecek kesiapan } \\
\text { android siswa berkaitan } \\
\text { dengan jaringan internet }\end{array}$ & 28 Guru & $100 \%$ & 0 Guru & $0 \%$ \\
\hline 7 & $\begin{array}{l}\text { Guru melakukan pengiriman } \\
\text { link ujian }\end{array}$ & 27 Guru & $96,43 \%$ & 1 Guru & $3,57 \%$ \\
\hline 8 & $\begin{array}{l}\text { Guru membuat group WA } \\
\text { kelas }\end{array}$ & 28 Guru & $100 \%$ & 0 Guru & $0 \%$ \\
\hline 9 & $\begin{array}{l}\text { Guru melakukan pengiriman } \\
\text { link ujian ke grup WA siswa }\end{array}$ & 28 Guru & $100 \%$ & 0 Guru & $0 \%$ \\
\hline 10 & $\begin{array}{l}\text { Guru dapat melihat hasil } \\
\text { ujian }\end{array}$ & 27 Guru & $96,43 \%$ & 1 Guru & $3,57 \%$ \\
\hline
\end{tabular}

Berdasarkan hasil pengamatan penerapan ulangan berbasis android pada siklus II yang dapat dilihat dari jumlah prosentase hampir keseluruhan mencapai $96,11 \%$ sehingga 
penelitian ini dinyatakan berhasil dengan indikator semua guru memahami dan menerapkan langkah-langkah pembuatan ulangan berbasis android.

Tabel 6. Peningkatan Presentase Siklus I Dan Siklus II

\begin{tabular}{|c|c|c|c|c|}
\hline No & Indikator langkah-langkah & $\begin{array}{c}\% \\
\text { Pada siklus } \\
1\end{array}$ & $\begin{array}{c}\% \\
\text { Pada siklus } \\
\text { II }\end{array}$ & $\begin{array}{c}\% \\
\text { Peningkatan }\end{array}$ \\
\hline 1 & $\begin{array}{l}\text { Guru melakukan konfigurasi akun } \\
\text { google/google drive }\end{array}$ & $50 \%$ & $50 \%$ & $50 \%$ \\
\hline 2 & Guru melakukan login akun google & $78,57 \%$ & $100 \%$ & $21,43 \%$ \\
\hline 3 & $\begin{array}{l}\text { Guru melakukan pembuatan } \\
\text { template soal }\end{array}$ & $57,14 \%$ & $82,14 \%$ & $25 \%$ \\
\hline 4 & Guru melakukan input soal & $85,71 \%$ & $100 \%$ & $14,29 \%$ \\
\hline 5 & $\begin{array}{l}\text { Guru melakukan penyetingan form } \\
\text { limiter }\end{array}$ & $75 \%$ & $85,71 \%$ & $10,71 \%$ \\
\hline 6 & $\begin{array}{l}\text { Guru mengecek kesiapan android } \\
\text { siswa berkaitan dengan jaringan } \\
\text { internet }\end{array}$ & $100 \%$ & $100 \%$ & - \\
\hline 7 & $\begin{array}{l}\text { Guru melakukan pengiriman link } \\
\text { ujian }\end{array}$ & $39,29 \%$ & $92,86 \%$ & $53,57 \%$ \\
\hline 8 & Guru membuat group WA kelas & $100 \%$ & $100 \%$ & - \\
\hline 9 & $\begin{array}{l}\text { Guru melakukan pengiriman link } \\
\text { ujian ke grup WA siswa }\end{array}$ & $100 \%$ & $100 \%$ & - \\
\hline 10 & Guru dapat melihat hasil ujian & $64,29 \%$ & $96,43 \%$ & 32,14 \\
\hline
\end{tabular}

Berdasarkan tabel diaas dapat dilihat dari hasil jumlah prosentase pada siklus 1 dan II, pada siklus II semua guru sudah memahami dan menerapkan langkah-langkah pembuatan soal ulangan berbasis android dengan fasilitas google form sehingga telah terjadi peningkatan.

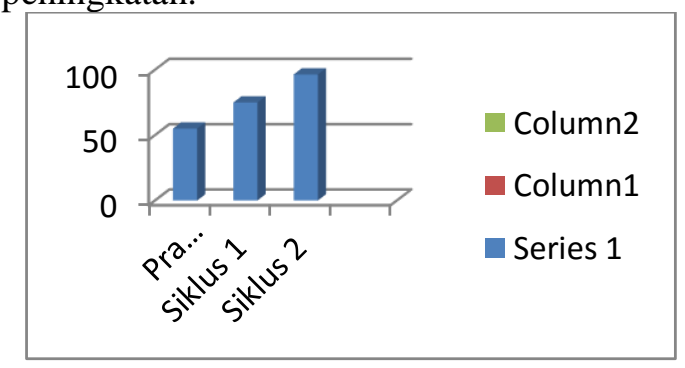

Grafik1. Peningkatan Kompetensi Guru Sebelum Dilakukan Tindakan Hingga Pemberikan Tindakan

\section{SIMPULAN DAN SARAN} Simpulan

Berdasarkan hasil penelitian dan data yang dihimpun, maka dapat disimpulkan sebagai berikut: (1) Berdasarkan angket dan wawancara, seluruh guru memiliki motivasi tinggi dalam mengikuti pelatihan ulangan berbasis Android; (2) Sebelum dilaksanakan pelatihan, guru belum pernah melaksanakan ulangan berbasis android pada ulalanga harian, Penilaian tengah semester dan Penilaian Akhir semester; (3) Pelatihan dan penerapan Ulangan berbasis android dapat meningkatkan kompetensi guru di SMAN 1 Belimbing; (4) Penerapan Ulangan berbasis android merupakan hal yang praktis, efektif dan efisien; (5) Seluruh guru memahami bahwa pentingnya mempelajari kegiatan yang menunjang dalam proses belajar mengajar 
yang berhubungan dengan Ilmu teknologi untuk meningkatkan kompetensi guru dalam mengajar; (6) Pada siklus 1, sebanyak 21 guru atau $75 \%$ sudah mengerti langkah-langkah membuat soal ulangan berbasis android dan menerapkan Ulangan berbasis android pada Penilaian Tengah Semester; dan (7) Pada siklus 2, sebanyak 27 guru atau 96, $43 \%$ guru sudah mengerti langkah-langkah membuat soal ulangan berbasis android dan menerapkan Ulangan berbasis android pada Penilaian Akhir Semester.

\section{Saran}

Dalam Penerapan Ulangan berbasis android (1) Perlu adanya peningkatan kwalitas jaringan internet sehingga tidak menghambat pelaksanaan ulangan berbasis android di sekolah; (2) Siswa diwajibkan membawa Handphone pada proses Ulangan berlangsung atau sekolah memfasilitasi keperluan siswa pada proses ulangan berlangsung dan (3) Ulangan berbasis Android menggunakan google form mempunyai kelebihan dan kekurangan. Dalam ulangan sedang berlangsung hendaknya pengawas lebih teliti agar siswa tidak mengakses jawaban melalui internet.

DAFTAR PUSTAKA

Arikunto, S. dkk (2008). Prosedur Penelitian: Suatu Praktek. Jakarta: Rineka Cipta

Batubara, Hamdan Husein. (2016). Penggunaan Google Form Sebagai Alat Penilaian Kinerja Dosen di Prodi PGMI UNISKA Muhammad Arsyad Al
Banjari. Al-Bidayah; Jurnal Pendidikan Dasar Islam, Volume 8(No. 1).

David Hopkins. (2011). Panduan Penelitian Tindakan Kelas. Yogyakarta: Pustaka Belajar

Farida Sarimaya, (2008) Sertifikasi Guru. Bandung: Yrama Widya

Mardiana, T., \& Purwanto, A. W. (2017). Google Form Sebagai Alternatif Pembuatan Latihan Soal Evaluasi. Universty Research Colloquium

Mutadi. (2018). Panduan Google Form. Semarang

Rochiati Wiriatdmadja. (2015). Metode Penelitian Tindakan Kelas. Bandung: PT. Remaja Rosdakarya

Sugiyono. (2010). Metode Penelitian Pendidikan Pendekatan Kuantitatif Kualitatif dan $R \& D$. Bandung: Alfabeta

Sohibun, S., \& Ade, F. Y. (2018). Pengembangan Media Pembelajaran Berbasis Virtual Class Berbantuan Google Drive. Tadris: Jurnal Keguruan Dan Ilmu Tarbiyah, 2(2), 121.

Suryana, Oya. (2008). Tutorial Google Form. Bandung.

https://www.academia.edu/37119292/M embuat_Soal_dan_Penilaian_Online_D engan_Google_Form diunduh tanggal 10 September 2019

Tim Penyusun Kamus. (1989) Kamus Besar Bahasa Indonesia, Jakarta: Balai Pustaka

Undang-undang Guru dan Dosen NO. 14/2005 dan Peraturan Pemerintah No. $19 / 2005$ 